\title{
RODITELJSKI PRITISAK I KVALITETA ŽIVOTA MLADIH SPORTAŠA
}

\author{
IVA GLIBO, RENATA BARIĆ \\ Kineziološki fakultet Sveučilišta u Zagrebu, kontakt: renata.baric@kif.hr
}

Primljeno: 12.1.2016.

Izvorni znanstveni rad

Prihvaćeno: 15.12 .2016 .

UDK: $796: 316.6$

Sažetak: Cilj ovog rada bio je ispitati razlike u kvaliteti života (KŽ) mladih sportaša i nesportaša, provjeriti metrijske karakteristike Upitnika roditeljskog pritiska u sportu (URPS) te ispitati povezanost između roditeljskog pritiska i KŽ. Uzorak sudionika čini 100 mladih sportaša prosječne dobi 12.4 godine i 71 nesportaš prosječne dobi 12.5 godina.

Kvaliteta života procijenjena je upitnikom The Kidscreen - 52 koji broji 11 dimenzija. Utvrđeno je da se mladi sportaši i mladi nesportaši ne razlikuju u ukupnoj procjeni kvalitete života. Značajna razlika utvrđena je na razini faktora tjelesne dobrobiti $i$ obiteljskog okruženja. Sportaši izvješćuju o višoj razini tjelesne dobrobiti, a nesportaši o višem zadovoljstvu obiteljskim okruženjem. Za procjenu roditeljskog pritiska prvi je puta korišten URPS čije su metrijske karakteristike pokazale zadovoljavajuću pouzdanost, no nešto slabiju osjetljivost. Faktorskom analizom ekstrahirana su dva faktora roditeljskog pritiska nazvana roditeljski kriticizam $i$ roditeljska očekivanja. Utvrđeno je da postoji negativna povezanost između roditeljskog kriticizma i KŽ, dok nije utvrđena značajna povezanost između roditeljskih očekivanja i KZ̆.

Ključne riječi: Kidscreen-52, roditeljski kriticizam, roditeljska očekivanja, kvaliteta života, sport, mladi sportaši

\section{UVOD}

Kvalitetu života (KŽ) Krizmanić i Kolesarić (1989) definiraju kao subjektivno doživljavanje vlastitog života određeno objektivnim okolnostima u kojima osoba živi, te karakteristikama ličnosti koje utječu na doživljaj realnosti i njenog specifičnog životnog iskustva. S obzirom na činjenicu da tjelesna aktivnost dokazano djeluje u prevenciji niza somatskih bolesti te doprinosi psihološkom zdravlju pojedinca (Biddle i Mutrie, 2008), kvalitetu života zanimljivo je promatrati s kineziološkog stajališta. Da tjelesna aktivnost utječe na kvalitetu života pokazali su Pucci i suradnici (2012), koji zaključuju da se u gotovo svim provedenim studijama vidi značajna pozitivna veza između razine tjelesne aktivnosti i različitih domena percepcije kvalitete života kod odraslih. Literatura ne nudi previše saznanja o kvaliteti života mladih, iako je vidljiv porast interesa za tu problematiku (RavensSieberer i sur., 2001). Povezanost kvalitete života i tjelesne aktivnosti istraživali su Shoup i suradnici (2008) na uzorku djece u dobi od 8-12 godina, te navode da manje tjelesno aktivna djeca imaju znatno lošiji rezultat u psihosocijalnoj domeni KŽ kao i u ukupnom doživljaju KŽ. U Hrvatskoj je prvom primjenom upitnika The Kidscreen-52 Lorger (2011) utvrdila da hrvatski adolescenti svoju kvalitetu života procjenjuju vrlo visokom. Mladići kvalitetu života procjenjuju višom prvenstveno zato što su njihove procjene tjelesne dobrobiti veće te su zadovoljniji sadržajima i načinima korištenja slobodnog vremena, dok su djevojke više zabrinute za izgled što im u ovoj dobi smanjuje opće zadovoljstvo životom. Lorger (2011) ističe veći doživljaj kvalitete života mladih sportaša i to na račun više procjene zdravlja, veće uključenosti u sportske aktivnosti, više sportske forme i razine energije, dok su nesportaši više vezani uz obitelj i školske obveze i manje aktivni, a njihov je doživljaj kvalitete života niži. To je sukladno nalazima prethodnih istraživanja, po kojima se sudjelovanje u sportu povezuje s većim uloženim naporom, višom razinom koncentracije i motivacije nego sudjelovanje u nekim drugim aktivnostima, kao što je škola ili druženje s prijateljima (Holt i sur., 2008). Mnogo je znanstvenih dokaza koji podupiru tezu da sport pozitivno utječe na zdravlje i socijalni razvoj, zbog čega veliki broj roditelja i upisuje djecu u sport- 
ske aktivnosti. Sportsko okruženje nudi priliku za učenje vještina i stavova važnih u odrasloj dobi (Smith i Smoll, 2002), omogućava razvoj samopoštovanja, ustrajnosti i intrinzične motivacije kod mladih sportaša (Duda, 1992; Slutzky i Simpinks, 2009; Fry i Newton, 2003), a zdravo i pozitivno sportsko okruženje koje podržava proces samootkrivanja i razvojne karakteristike djece i mladih doprinosi psihosocijalnom razvoju i usvajanju adaptivnih obrazaca ponašanja i doživljavanja (Petitpas i sur., 2005). Međutim, rana selekcija i uključivanje u sustav natjecanja obvezuju djecu; sport uz školu postaje dominantan, a djeci često nedostaje vremena za igru i druge aktivnosti. U tom procesu odrastanja i djetetove sportske karijere na doživljaj kvalitete života negativno mogu djelovati razni okolinski faktori, a jedan od značajnijih je pritisak roditelja.

\section{Roditeljski pritisak i mladi sportaš}

Roditeljska je uloga u razvoju talenta djece višestrana i mijenja se sukladno dječjoj dobi. S obzirom na stupanj angažmana i uključenosti u sport djeteta roditelji mogu biti premalo, umjereno ili previše angažirani (Hellstedt, 1987). Djeci nedostatno angažiranih roditelja može nedostajati potrebnih sredstava i emocionalne potpore razvoju sportske karijere; oni traže potporu u drugim značajnim odraslima kao što su učitelj ili trener te postoji veća vjerojatnost da će odustati od bavljenja sportom (Hellstedt, 1987). Najpoželjnijim se smatra umjereni roditeljski angažman; takvi roditelji pružaju optimalan stupanj poticaja i podrške ne naglašavajući pretjerano važnost pobjede (Hellstedt, 1990). Djeca previše angažiranih roditelja visoki stupanj roditeljske angažiranosti često percipiraju i kao pritisak. Problem nastaje kad mladi sportaši osjećaju da su izgubili kontrolu nad odlukama vezano uz sudjelovanje u sportu (Cumming i Ewing, 2002). Dokazano je da takva djeca manje uživaju i slabije su motivirana za sport (Sánchez-Miguel i sur., 2013), a takvi se roditelji često sukobljavaju s trenerima i skoni su miješati se u trenerski posao. Roditeljski pritisak izaziva niz neadaptivnih reakcija kod djece, od razvoja natjecateljske anksioznosti (O`Rourke i sur., 2011), psihosomatskih reakcija, straha od negativne evaluacije (Sagar i Stoeber, 2009), pada samopouz- danja (Hoyle i Leff, 1997) i potrebe za izbjegavanjem prijetećih situacija koje narušavaju integritet mladog sportaša, što dugoročno dovodi do pada motivacije i odustajanja (Partridge i sur., 2008). Međutim, roditeljski pritisak ne može se odrediti jednoznačno za sve mlade sportaše jer percepcija pritiska može varirati s obzirom na odnos roditelja i djeteta te djetetovu motivaciju. Ono što jedno dijete percipira kao pritisak drugo može percipirati kao potporu (Sack i sur., 2008). U istraživanju percepcije roditeljskog pritiska na uzorku mladih skijaša Hellstedt (1990) definira roditeljski pritisak kao količinu motivacijskog utjecaja roditelja na mladog sportaša da se natječe, da nastupi na određenoj razini i da nastavi bavljenje sportom. Kada se radi o pritisku da se natječu, $72.8 \%$ mladih skijaša navelo je svoje roditelje kao izvor umjerenog ili jakog pritiska, a 26\% sudionika izjavilo je da su ih roditelji natjerali da se natječu. Rezultati su također pokazali da s porastom pritiska raste i negativni odgovor sportaša. Kao odgovor na pitanje kako bi reagirali roditelji u slučaju odustajanja od sporta samo $12 \%$ ispitanika odgovorilo je da roditelji ne bi bili uznemireni. Većina sudionika izvjestila je o srednjem do jakom pritisku, ali mnogi od njih ne vide pritisak kao negativnu stvar, već kao pozitivnu potporu. Povezanost roditeljske podrške i pritiska sa zadovoljstvom koje mladi tenisači osjećaju vezano uz bavljenje sportom, nastupom, samopouzdanjem i ostalim karakteristikama ispitivali su Hoyle i Leff(1997). Rezultati su pokazali da je roditeljska podrška u pozitivnoj korelaciji sa zadovoljstvom, $\mathrm{s}$ razinom na kojoj su sportaši nastupali i s važnosti koju su tenisači pripisali nastupu. Međutim, rezultati nisu pokazali da roditeljski pritisak ima važan utjecaj na participaciju i natjecateljski nastup mladih tenisača. Wuerth i suradnice (2004) dolaze do zaključka kako aktivna roditeljska uključenost (npr. pohvala i razumijevanje) ne koreliraju s pritiskom. Jedina dimenzija koja je u vezi s pritiskom je direktivno ponašanje roditelja. Kvalitativno istraživanje Defrancesca i Johnsona (1997, prema Lauer i sur., 2010) otkriva da se manji dio mladih sportaša osjećao neugodno zbog roditeljskog ponašanja na sportskom nastupu (29\%), koje je obuhvaćalo odlaženje sa terena, vikanje na dijete ili fizičko kažnjavanje nakon nastupa. Također, Lauer i suradnici (2010) navode da je kritičko ponašanje, pretjerano forsiranje djeteta, prenaglašavanje pobjede i razvo- 
ja sportskog talenta u odnosu na druge domene djetetova života te kontroliranje djetetova ponašanja kako bi se dosegli ciljevi u tenisu- inhibirajuće za djetetov razvoj. Do sličnih rezultata dosli su i Omli i Bjornstal (2011) koji su u svojoj kvalitativnoj studiji ispitali djecu o ponašanju roditelja za vrijeme utakmica i sportskih događanja. Ponašanja koja su pozitivno ocijenjena su sjedenje u tišini, navijanje, ohrabrivanje, pohvala, empatija i zaštitna intervencija. Djeca su izrazila nezadovoljstvo kada su se roditelji ponašali kao treneri dajući im instrukcije, savjete i kritike te kada su se svađali, krivili druge za njihov loš potez, davali pogrdne komentare, vikali, ometali ih i fanatično navijali, a većina roditeljskih komentara na utakmicama je negativna ili instruktivna (Holt i sur., 2008). Sumarno gledano, roditelji mogu biti snažan izvor podrške ali i pritiska mladom sportašu, što može utjecati na sportski razvoj i razinu te duljinu bavljenja sportom. Činjenica je da se velik broj djece uključuje $\mathrm{u}$ organizirane sportske programe, no ulaskom u pubertet evidentno je da ih većina odustaje (FraserThomas i sur., 2008; Horga, 2009). Djetinjstvo i mladost su najvažnija formativna razdoblja, a neki se segmenti razvoja, npr. specifična motorička znanja mogu razviti samo sredstvima koja se koriste $u$ sportu (Doupona i Petrovič, 1997). Aktivni životni stil je nešto čemu teži suvremeno društvo te bi bilo važno razumjeti na koji način sportom možemo pozitivno djelovati ne samo na motorički, nego i na psihološki razvoj, te opće zadovoljstvo sobom i svojim životom, te koji su to rizični faktori koji mogu narušiti doživljaj kvalitete života mladih koji se bave sportom i potaknuti njihovo odustajanje.

\section{CILJ I HIPOTEZE}

Cilj je ovog istraživanja ispitati razlike u doživljaju kvalitete života mladih sportaša i nesportaša, provjeriti metrijske karakteristike Upitnika roditeljskog pritiska u sportu, te ispitati povezanost između roditeljskog pritiska i kvalitete života. Sukladno nalazima dosadašnjih istraživanja inicijalno možemo pretpostaviti da mladi sportaši kvalitetu svog života procjenjuju višom na račun viših procjena tjelesne dobrobiti i zdravlja, zadovoljstva sadržajima i načinima korištenja slobodnog vremena, uključenosti u sportske aktivnosti te procjena sportske forme i razine energije $u$ odnosu na nes- portaše, no da u ukupnom doživljaju kvalitete života neće biti razlike s obzirom na razinu sportske uključenosti. Nadalje, pretpostavlja se da postoji značajna negativna povezanost između doživljaja roditeljskog pritiska i doživljaja kvalitete života kod djece koja se bave sportom.

\section{METODE RADA}

Sudionici i postupak. U istraživanju je sudjelovalo ukupno 171 sudionika, 100 mladih sportaša i 71 nesportaš muškog spola. Sportaši su bili aktivni natjecatelji u svom sportu te su redovito trenirali 16 različitih sportova, ekipnih i individualnih. Podaci su prikupljani u sportskim klubovima i u nekoliko osnovnih škola u razdoblju od listopada 2012. do veljače 2013. godine. Za sudjelovanje u istraživanju dobivena je pismena suglasnost roditelja ili skrbnika, te su poštivana načela Etičkog kodeksa istraživanja $s$ djecom (Ajduković i Kolesarić, 2003). Sudionici su bili stari od 10 do 14 godina, prosječne dobi $12.4 \operatorname{god}$. $(S D=1.33),\left(M_{\text {sportaši }}=12.4\right.$ g., $S D=1.43, M_{\text {nesportaši }}=12.5 \mathrm{~g}$., $S D=1.19$ ).

Instrumenti $i$ varijable. Za procjenu kvalitete života korištena je hrvatska verzija upitnika The Kidscreen-52 (Lorger i Barić, 2012) koja sadrži ukupno 11 dimenzija kojima se obuhvaća opširan koncept KŽ, a to su: tjelesna dobrobit ("Jesi li se osjećao dobro i u formi?”), psihološka dobrobit (“Jesi li se osjećao sretnim što postojiš?”), raspoloženje i neugodne emocije ("Jesi li bio tužan?"), samopoimanje ("Jesi li bio zadovoljan samim sobom?"), slobodno vrijeme ("Jesi li imao dovoljno vremena za sebe?"), odnosi s roditeljima (“Jesu li te roditelji razumjeli?"), novac ("Jesi li imao dovoljno novaca za svoje troškove?"), prijateljstvo (“Jesi li se zabavljao sa svojim prijateljima?"), školsko okruženje ("Je li ti u školi dobro išlo?") i nasilje ("Jesi li se bojao drugih djevojčica i dječaka?”). U zaglavlju upitnika dodana je jedna čestica koja ispituje stupanj uključenosti u sport i vrstu sporta. Procjene se daju na skali od 5 stupnjeva (nikad-uvijek), a pri ispunjavanju zadatak je razmišljati o proteklom tjednu. Viši rezultat ukazuje na veći doživljaj kvalitete života, osim višeg rezultata na dimenziji raspoloženje i neugodne emocije i na dimenziji nasilje koji znače veću zastupljenost negativnih emocija i izloženost nasilju vršnjaka, što narušava doživljaj kvalitete života. Uz navedeni 
upitnik po prvi puta je korišten i Upitnik roditeljskog pritiska u sportu (URPS) kreiran za potrebe ovog istraživanja, koji je u inicijalnoj verziji sadržavao ukupno 15 čestica, a korišten je u dvije forme, za majku i za oca. Upitnik su ispunjavali samo mladi sportaši. Sudionici su ocjenjivali tvrdnje i odgovarali na pitanja na Likertovoj petstupanjskoj ljestvici (1-uopće ne/ nikad; 5-izrazito jako/uvijek). Finalna verzija sadrži 9 čestica koje se kondenziraju na dvije dimenzije temeljem prosječnih vrijednosti, a to su roditeljski kriticizam ("Čak i kad pobijedim uvijek dobijem neku kritiku”) i roditeljska očekivanja ("Moji roditelji očekuju da postanem vrhunski sportaš"). Viši rezultat na obje podljestvice označava izraženiji doživljaj roditeljskog pritiska.

Metode obrade podataka. Deskriptivna analiza svih varijabli provedena je za poduzorke sportaša i nesportaša. Izračunat je Cronbachov alfa koeficijent kao mjera pouzdanosti The Kidscreen-52 upitnika za djecu i adolescente. Na poduzorku sportaša provedena je i deskriptivna analiza rezultata na URPS kao i mjere asimetrije distribucije odgovora. Normalitet distribucije testiran je KolmogorovSmirnovljevim testom. Potom je provedena faktorska analiza te provjerena pouzdanost dobivenih dimenzija URPS. Za testiranje razlika u KŽ između sportaša i nesportaša korištena je univarijatna analiza varijance, a povezanost dimenzija $K Z \check{~}$ i dimenzija roditeljskog pritiska provjerena je Pearsonovim koeficijentom korelacije.

\section{REZULTATI I RASPRAVA}

\section{Faktorska struktura Upitnika roditeljskog pritiska u sportu}

Nakon provedenog niza eksploratornih faktorskih analiza primjenjujući ortogonalnu varimax rotaciju i uz uvjet supresije koeficijenata korelacije ispod 0.40 te uz unaprijed zadani broj faktora (2), ekstrahirana su dva faktora koja objašnjavaju najveći dio varijance rezultata koji se odnose i na obje verzije upitnika, i za majku i za oca. Prethodno su neke čestice isključene iz daljnje analize budući da su njihove korelacije s ukupnim rezultatom bile neznačajne, a njihova varijanca podijeljena po faktorima. Tako je formirana konačna verzija URPS od 9 čestica koje se grupiraju u dva faktora rodi- teljskog pritiska: roditeljski kriticizam i roditeljska očekivanja (tablica 1).

U upitniku za majke prvi faktor objašnjava $29.87 \%$, a u upitniku za očeve $37.7 \%$ varijance rezultata. Prvi faktor čine tvrdnje koje se odnose na roditeljsko glasno komentiranje i instruktivno ponašanje $s$ tribina na sportskim događajima, vikanje na suce, kritiku koju djeca dobiju nakon nastupa čak i u slučaju pobjede, odnos kritike i pohvale koja ide u korist kritike te roditeljsko "pametovanje" čak i kada djeca smatraju da roditelj ne zna dovoljno o sportu. Prvi je faktor prema tome nazvan roditeljski kriticizam.

Drugi faktor u upitniku za majke objašnjava $22.6 \%$, a u upitniku za očeve $21.57 \%$ ukupnog variranja rezultata. Čestice se odnose na visoke ciljeve u sportu koje roditelji postavljaju djeci, dječji osjećaj da roditelj više želi da se ono bavi sportom nego ono samo te na pritisak vezan uz odustajanje od sporta. Drugi se faktor može nazvati roditeljska očekivanja.

Tablica 1. Matrica faktorske strukture Upitnika roditeljskog pritiska u sportu za majke (M) i očeve (O)

\begin{tabular}{|c|c|c|c|}
\hline \multicolumn{2}{|c|}{ Cestice } & Roditeljski kriticizam & Roditeljska očekivanja \\
\hline \multirow{2}{*}{1} & $\mathrm{M}$ & $\mathbf{0 . 4 7}$ & -0.05 \\
\cline { 2 - 4 } & $\mathrm{O}$ & $\mathbf{0 . 4 9}$ & 0.40 \\
\hline \multirow{2}{*}{2} & $\mathrm{M}$ & $\mathbf{0 . 7 9}$ & 0.13 \\
\cline { 2 - 4 } & $\mathrm{O}$ & $\mathbf{0 . 8 5}$ & 0.20 \\
\hline \multirow{3}{*}{3} & $\mathrm{M}$ & $\mathbf{0 . 5 3}$ & 0 \\
\cline { 2 - 4 } & $\mathrm{O}$ & $\mathbf{0 . 6 8}$ & 0.04 \\
\hline \multirow{3}{*}{4} & $\mathrm{M}$ & $\mathbf{0 . 7 3}$ & 0.10 \\
\cline { 2 - 4 } & $\mathrm{O}$ & $\mathbf{0 . 8 5}$ & 0.19 \\
\hline \multirow{3}{*}{5} & $\mathrm{M}$ & $\mathbf{0 . 7 1}$ & -0.04 \\
\cline { 2 - 4 } & $\mathrm{O}$ & $\mathbf{0 . 8 9}$ & 0.10 \\
\hline \multirow{2}{*}{6} & $\mathrm{M}$ & 0.41 & $\mathbf{0 . 5 3}$ \\
\cline { 2 - 4 } & $\mathrm{O}$ & 0.28 & $\mathbf{0 . 7 4}$ \\
\hline \multirow{2}{*}{7} & $\mathrm{M}$ & -0.04 & $\mathbf{0 . 8 6}$ \\
\cline { 2 - 4 } & $\mathrm{O}$ & 0.09 & $\mathbf{0 . 7 9}$ \\
\hline \multirow{2}{*}{8} & $\mathrm{M}$ & -0.14 & $\mathbf{0 . 8 8}$ \\
\cline { 2 - 4 } & $\mathrm{O}$ & 0.05 & $\mathbf{0 . 7 1}$ \\
\hline 9 & $\mathrm{M}$ & $\mathbf{0 . 5 8}$ & 0.48 \\
\cline { 2 - 4 } & $\mathrm{O}$ & $\mathbf{0 . 5 9}$ & 0.13 \\
\hline
\end{tabular}

U tablici 2 vidljivo je da je aritmetička sredina za oba faktora roditeljskog pritiska za majke identična i pokazuje kako se većina odgovora smjestila u zonu nižih vrijednosti te da je krivulja distribucije rezultata pozitivno asimetrična. Cronbachove alfe 
su zadovoljavajućih, ali ne i optimalnih vrijednosti (Everitt, 2002). Aritmetičke sredine na oba su faktora roditeljskog pritiska za očeve veće od onih na upitniku za majke što pokazuje kako mladi sportaši doživljavaju veći pritisak u obliku kriticizma i očekivanja od očeva nego od majki $(t=3.106$; $d f=95, p<.002)$. Ovakav rezultat je očekivan i već potvrđen u prethodnim istraživanjima (Stein i sur., 1999) te ima uporište u činjenici da očevi vjerojatnije objektivno imaju ili tvrde da imaju veće znanje o sportu i interes za njega od majki (Coakley, 2006). Prethodno je također utvrđeno da samo očinski, a ne i majčinski pritisak negativno korelira s generalnim uživanjem i stavovima o sportu (Kanters i Casper, 2008). Standardne devijacije jednakih su vrijednosti te izražavaju veće variranje rezultata u odnosu na upitnik za majke. Koeficijent pouzdanosti idealan je za očinski kriticizam i prihvatljiv za očinska očekivanja (Everitt, 2002).

Tablica 2. Deskriptivni pokazatelji i pouzdanost faktora Upitnika roditeljskog pritiska u sportu za majke i očeve

\begin{tabular}{|l|c|c|c|c|}
\hline Faktori & & AS & SD & $\boldsymbol{\alpha}$ \\
\hline \multirow{2}{*}{ Roditeljski kriticizam } & $\mathrm{M}$ & 1.31 & 0.45 & 0.70 \\
\cline { 2 - 5 } & $\mathrm{O}$ & 1.45 & 0.70 & 0.84 \\
\hline Roditeljska očekivanja & $\mathrm{M}$ & 1.31 & 0.59 & 0.68 \\
\cline { 2 - 5 } & $\mathrm{O}$ & 1.41 & 0.70 & 0.65 \\
\hline
\end{tabular}

Legenda: AS - aritmetička sredina, SD- standardna devijacija, $\alpha-$ Cronbachova alfa

Aritmetička sredina na oba faktora ima slične, gotovo jednake vrijednosti (Tablica 3). Većina rezultata priklonila se nižim vrijednostima te je distribucija pozitivno asimetrična. Standardne devijacije pokazuju da rezultati više variraju u dimenziji roditeljska očekivanja. Mjere pouzdanosti su niže, ali prihvatljivih sličnih vrijednosti za obje dimenzije URSP (Everitt, 2002).

Tablica 3. Deskriptivni pokazatelji i pouzdanost faktora Upitnika roditeljskog pritiska u sportu (za majke i očeve zajedno)

\begin{tabular}{|l|c|c|c|}
\hline Faktor & AS & SD & $\boldsymbol{\alpha}$ \\
\hline Roditeljski kriticizam & 1.36 & 0.49 & 0.66 \\
\hline Roditeljska očekivanja & 1.35 & 0.56 & 0.67 \\
\hline
\end{tabular}

Legenda: AS - aritmetička sredina, SD- standardna devijacija, $\alpha-$ Cronbachova alfa

Deskriptivni pokazatelji i metrijske karakteristike Upitnika roditeljskog pritiska u sportu
Iz tablice 4 vidljivo je da variranje aritmetičkih sredina čestica upućuje na pozitivno asimetričan oblik distribucije rezultata upitnika za majke. Standardne devijacije upućuju na malo variranje rezultata od aritmetičke sredine. U upitniku za očeve standardne devijacije su nešto veće nego na upitniku za majke, ali i dalje se najčešće kreću do 1 . Normalitet distribucije testiran je Kolmogorov-Smirnovljevim testom koji je pokazao da se distribucija rezultata po pojedinim česticama na razini značajnosti $p=0.01$ razlikuje od normalne. Radi dodatne provjere testa normaliteta distribucije proveden je i Shapiro-Wilksovov test koji je također potvrdio rezultate prethodne provjere. Petz (1997, str. 36) navodi ako su uzorci veći od $n=30$, "distribucija aritmetičkih sredina je normalna čak i onda ako osnovna populacija nije normalno raspodijeljena" pa se zbog te činjenice i zbog veličine uzorka moglo nastaviti s analizom rezultata parametrijskim metodama.

Od metrijskih karakteristika URPS upitnika provjerene su pouzdanost i osjetljivost. Osjetljivost je procijenjena pomoću mjera izduženosti i zakrivljenosti. Mjera zakrivljenosti (skewness) u svim česticama upitnika za majke i očeve ima vrijednost veću od jedan što upućuje na pozitivnu asimetričnost distribucije (Tablica 4). Većina koeficijenata izduženosti ima visoke vrijednosti. Tri čestice imaju platikurtičnu, jedna mezokurtičnu, a šest čestica ima leptokurtičnu distribuciju rezultata. S obzirom na to da kriteriji osjetljivosti za većinu čestica nisu zadovoljeni može se zaključiti URPS nema zadovoljavajuću osjetljivost, no to može biti i odraz realne situacije, budući da se takva ekstremna ponašanja roditelja u biti ne javljaju često.

Interna konzistencija testa izražena Cronbachovim alfa koeficijentom, za upitnik koji se odnosi na majke $\alpha$ iznosi 0.71 , a za očeve 0.83 . Prema nekim uputama za interpretaciju (Everitt, 2002) rezultat od 0.80 do 0.90 smatra se vrlo dobrim, a od 0.70 do 0.80 dobrim pa se i pouzdanost ovoga upitnika može smatrati zadovoljavajućom.

Deskriptivni pokazatelji upitnika The Kidscreen-52 dobiveni na uzorku sportaša i nesportaša

Mjere raspršenja rezultata (tablica 5) pokazuju da su se rezultati grupirali u području visokih vrijednosti 
Tablica 4. Deskriptivni pokazatelji Upitnika roditeljskog pritiska u sportu

\begin{tabular}{|c|c|c|c|c|c|}
\hline \multicolumn{2}{|c|}{ Cestice } & AS & SD & Skewness & Kurtosis \\
\hline 1 & $\mathrm{M}$ & 1.37 & 0.77 & 2.22 & 4.31 \\
\hline & $\mathrm{O}$ & 1.51 & 0.99 & 1.92 & 2.54 \\
\hline 2 & $\mathrm{M}$ & 1.17 & 0.50 & 3.41 & 13.11 \\
\hline & $\mathrm{O}$ & 1.47 & 0.99 & 2.14 & 3.64 \\
\hline 3 & $\mathrm{M}$ & 1.11 & 0.45 & 4.60 & 22.64 \\
\hline & $\mathrm{O}$ & 1.22 & 0.65 & 3.72 & 15.54 \\
\hline 4 & $\mathrm{M}$ & 1.48 & 0.90 & 2.28 & 5.12 \\
\hline & $\mathrm{O}$ & 1.65 & 1.15 & 1.70 & 1.59 \\
\hline 5 & $\mathrm{M}$ & 1.19 & 0.59 & 3.71 & 14.6 \\
\hline & $\mathrm{O}$ & 1.37 & 0.86 & 2.33 & 4.24 \\
\hline 6 & $\mathrm{M}$ & 1.36 & 0.69 & 2.05 & 3.84 \\
\hline & $\mathrm{O}$ & 1.48 & 0.90 & 1.91 & 3.00 \\
\hline 7 & $\mathrm{M}$ & 1.35 & 0.89 & 2.86 & 8.00 \\
\hline & $\mathrm{O}$ & 1.44 & 0.97 & 2.26 & 4.17 \\
\hline 8 & $\mathrm{M}$ & 1.22 & 0.68 & 3.67 & 14.43 \\
\hline & $\mathrm{O}$ & 1.32 & 0.87 & 2.97 & 8.22 \\
\hline 9 & $\mathrm{M}$ & 1.53 & 0.94 & 1.75 & 2.21 \\
\hline & $\mathrm{O}$ & 1.48 & 0.93 & 1.94 & 2.95 \\
\hline
\end{tabular}

Legenda: AS - aritmetička sredina, SD - standardna devijacija,O-očevi, M-majke

za sportaše i nesportaše što upućuje na zaključak da i sportaši i nesportaši svoj život doživljavaju ugodnim. Mjere pouzdanosti su za oba poduzorka iznad 0.70 (uz iznimku faktora samopoimanje gdje je dobivena niska pouzdanost) što upućuje na dobru pouzdanost upitnika The Kidsreen - 52 na ovome uzorku. Slične vrijednosti pouzdanosti istoga upitnika dobivene su i na studiji grčkih (Tzavara i sur., 2012), španjolskih (Tebe i sur., 2008) te koreanskih (Hong i sur., 2007) adolescenata. Također, Ravens - Sieberer i sur. (2014) našli su da je pouzdanost svih faktora The Kidscreen -52 upitnika u studiji koja je obuhvaćala 13 europskih zemalja iznad 0.77 . Vrijednost faktora samopoimanje u istraživanju na uzorku portugalskih adolescenata iznosila je 0.60 (Gaspar i sur., 2012) te procijenjena niskom. Slično tome, u ovom su istraživanju vrijednosti pouzdanosti za faktor samopoimanje izrazito niske vrlo vjerojatno stoga jer djeca zbog svoje dobi vjerojatno nisu razumjela pitanja te bi ih u mogućoj daljnjoj uporabi upitnika za tu dobnu skupinu trebalo drugačije formulirati.

Sudeći prema dobivenim rezultatima, za pozitivan doživljaj kvalitete života mladih sportaša prvenstveno su odgovorni faktori obiteljsko okru-
Tablica 5. Deskriptivni parametri-poduzorak sportaša (S) i nesportaša (N)

\begin{tabular}{|c|c|c|c|c|}
\hline \multicolumn{2}{|c|}{ Dimenzije kvalitete života } & AS & SD & $\alpha$ \\
\hline \multirow[t]{2}{*}{ Tjelesna dobrobit } & $\mathrm{S}$ & 4.06 & 0.58 & 0.71 \\
\hline & $\mathrm{N}$ & 3.76 & 0.70 & 0.74 \\
\hline \multirow[t]{2}{*}{ Psihološka dobrobit } & $\mathrm{S}$ & 4.19 & 0.53 & 0.80 \\
\hline & $\mathrm{N}$ & 4.30 & 0.64 & 0.89 \\
\hline \multirow[t]{2}{*}{ Raspoloženje i emocije } & $\mathrm{S}$ & 1.80 & 0.49 & 0.70 \\
\hline & $\mathrm{N}$ & 1.68 & 0.52 & 0.78 \\
\hline \multirow[t]{2}{*}{ Samopoimanje } & $\mathrm{S}$ & 2.45 & 0.64 & 0.49 \\
\hline & $\mathrm{N}$ & 2.49 & 0.60 & 0.31 \\
\hline \multirow[t]{2}{*}{ Slobodno vrijeme } & $\mathrm{S}$ & 3.88 & 0.90 & 0.89 \\
\hline & $\mathrm{N}$ & 4.07 & 0.91 & 0.91 \\
\hline \multirow[t]{2}{*}{ Obiteljsko okruženje } & $\mathrm{S}$ & 4.38 & 0.62 & 0.85 \\
\hline & $\mathrm{N}$ & 4.58 & 0.47 & 0.76 \\
\hline \multirow[t]{2}{*}{ Novac } & $\mathrm{S}$ & 4.08 & 0.82 & 0.82 \\
\hline & $\mathrm{N}$ & 4.19 & 0.81 & 0.86 \\
\hline \multirow[t]{2}{*}{ Druženje } & $\mathrm{S}$ & 3.99 & 0.81 & 0.71 \\
\hline & $\mathrm{N}$ & 3.95 & 0.79 & 0.81 \\
\hline \multirow[t]{2}{*}{ Prijatelji } & $\mathrm{S}$ & 4.27 & 0.71 & 0.74 \\
\hline & $\mathrm{N}$ & 4.11 & 0.88 & 0.84 \\
\hline \multirow[t]{2}{*}{ Školsko okruženje } & $\mathrm{S}$ & 3.80 & 0.75 & 0.85 \\
\hline & $\mathrm{N}$ & 3.75 & 0.79 & 0.71 \\
\hline \multirow[t]{2}{*}{ Nasilje } & $\mathrm{S}$ & 1.22 & 0.40 & 0.77 \\
\hline & $\mathrm{N}$ & 1.36 & 0.58 & 0.73 \\
\hline \multirow[t]{2}{*}{ Ukupna kvaliteta života } & $\mathrm{S}$ & 3.46 & 0.29 & 0.82 \\
\hline & $\mathrm{N}$ & 3.48 & 0.30 & 0.81 \\
\hline
\end{tabular}

Legenda: AS - aritmetička sredina, SD- standardna devijacija

ženje i prijatelji. Većina ih pozitivno doživljava svoje obiteljsko okruženje i interakciju s prijateljima. To ne čudi s obzirom na to da je uvažavanje prijatelja sportaša jedan od važnijih socijalnih uvjeta važan za proces treninga i natjecanja (Karković, 1998, prema Petrušić, 2012). Pozitivna percepcija odnosa s drugim važnim odraslima (trener i roditelji) te prijateljima je pozitivno povezana s većom motivacijom za sport, uživanjem u aktivnosti, manjim stresom, većom percepcijom kompetntnosti i intrinzičnom motivacijom (Ullrich-French i Smith, 2006). Također, pritisak koji dolazi od trenera i roditelja u pozitivnoj je korelaciji sa strahom od pogrešaka, sumnjom u vlastite sposobnosti i manjom percepijom sportske kompetentnosti kod mladih nogometaša (Ommundsen i sur., 2006). Sportaši svoju kvalitetu života percipiraju zadovoljavajućom i zbog novca, kojeg imaju dovoljno za sve svoje potrebe i psihološke te tjelesne dobrobiti koja je razumljivo na ovom uzorku visoka. 
Mladi nesportaši kao i sportaši svoj život doživljavaju pozitivno. Tome doprinose najviše visoki rezultati na faktoru obiteljskog okruženja i psihološke dobrobiti što znači da su nesportaši zadovoljni funkcioniranjem svoje obitelji i odnosima s roditeljima i ostalim članovima obitelji te doživljavaju svoj život zabavnim. Oni su zadovoljni i radosni što postoje te zadovoljni sobom u cjelini. Također imaju dosta novca na raspolaganju za svoje potrebe i slobodnog vremena kojim mogu upravljati. Zadovoljni su svojim društvenim životom te kvalitetom odnosa s vršnjacima i prijateljima. Rezultati pokazuju da negativne emocije i raspoloženja nisu tako često prisutni.

\section{Analiza razlika mladih sportaša i nesportaša}

Sportaši i nesportaši slično procjenjuju svoju kvalitetu života. Sukladno vrijednostima prosječnih ocjena nesportaši procjenjuju svoju KŽ nešto višom nego sportaši, a oba poduzorka je procjenjuju visokim ocjenama. Postoji relativno velika razlika u prosječnim rezultatima procjena pitanja koja čine faktor tjelesne dobrobiti, očekivano u korist sportaša.

Analiza varijance je pokazala, u skladu s postavljenom prvom hipotezom, da nema statistički značajne razlike između poduzorka mladih sportaša i nesportaša u ukupnoj percepciji kvalitete života $(F=0.071, d f=1, p<.79)$. Ovaj rezultat u skladu je s rezultatom koji je dobila Petrušić (2012) na uzorku adolescenata. Lorger (2011) je, suprotno navedenom, utvrdila da se sportaši i nesportaši adolescenti međusobno razlikuju u percepciji kvalitete života.

Od 11 faktora kvalitete života, statistički značajna razlika dobivena je na samo dva faktora: tjelesna dobrobit $(F=9.769, d f=1, p<.002)$ u korist sportaša i obiteljsko okruženje $(F=5.438, d f=1, p<.021) \mathrm{u}$ korist nesportaša.

Iako se osobe boljeg zdravlja vjerojatno češće uključuju u tjelesne aktivnosti, svakodnevna praksa i znanstvena istraživanja potvrđuju da veća količina tjelesne aktivnosti, u ovom slučaju sportski trening, pozitivno utječe na osjećaj zdravlja (Warburton i sur., 2006) i ima za posljedicu mnoge tjelesne dobrobiti (Jannsen i LeBlanc, 2010). Tjelesna dobrobit koju sportaši ostvaruju baveći se sportom može se sagledati kroz poboljšane funkcionalne i motoričke sposobnosti, osjećaj dobre tjelesne forme što je uvjet za postizanje dobrih rezultata $u$ sportu. Ovakav rezultat na ovom faktoru potpuno je očekivan i logičan te se podudara s rezultatima Petrušić (2012) i Lorger (2011) koje su provele istraživanja koristeći isti upitnik, ali na populaciji adolescenata. Sportaši su više okrenuti visokoj razini subjektivno procijenjenog zdravlja, visokoj razini sportske aktivnosti, visokoj razini sportske forme $\mathrm{i}$ ispunjenosti energijom, dok su procjene nesportaša u tom segmentu niže (Lorger, 2011).

Faktor obiteljskog okruženja mjeri razumijevanje roditelja za mladu osobu, osjećaj roditeljske ljubavi, sreću kod kuće, vrijeme provedeno s roditeljima, odnos roditelja te mogućnost razgovora s roditeljima. Nesportaši na ovom faktoru imaju statistički značajno veći rezultat od sportaša što je u skladu s rezultatima Lorger (2011). Kvalitetu sportaša determinira visoka razina tjelesne dobrobiti, a nesportaša nekih drugih elemenata poput malo većeg zadovoljstva odnosima u obitelji ili školi.

Razdoblje kasnog djetinjstva specifično je po tome što dijete sve više vremena provodi u odnosima izvan obitelji (Klarin, 2006). U životu mladih sportaša te dobi uz standardne (roditelji, braća, sestre, prijatelji, učitelji i sl.) javlja se još jedan važan socijalizacijski faktor - trener. Trener svojim ponašanjem može djelovati na oblikovanje nekih aspekata ličnosti sportaša, na motivaciju i sl., a može imati i važan odgojni utjecaj vidljiv preko oblikovanja djetetova sustava vrijednosti, razvoja socijalnih kompetencija, navika i pravila ponašanja (Barić i Horga, 2006). Trener ponekad u nekim segmentima zamjenjuje roditelja pa je moguće da on/ona preuzima jedan dio uobičajenog roditeljskog angažmana što bi možda objasnilo razliku između sportaša i nesportaša s obzirom da nesportaši nemaju takav utjecaj u svom životu, iako mogu imati slične, važne druge osobe' poput učitelja ili mentora na nekim drugim izvanškolskim aktivnsotima, no učestalost njihovog druženja u ovoj je dobi ipak manja nego količina druženja trenera i mladih sportaša-natjecatelja. Drugo moguće objašnjenje je da roditelji vršeći pritisak na djecu sportaše narušavaju odnose u obitelji. Takvi roditelji postaju toliko uključeni u život svoje djece da im postane teško emocionalno se odvojiti od dječjih iskustava. Oni često misle da je njihova odgovor- 
nost da podupiru dječje sportske fantazije ili ciljeve čak i ako ih djeca nemaju. Primarna zadaća koju bi roditelji svakog mladog sportaša trebali preuzeti jest pružanje emocionalne podrške koja uključuje pomaganje djetetu da se suoči s pobjedom i/ili porazom, razgovor o izvedbi, ohrabrivanje djeteta i pomaganje djetetu da shvati lekcije koje može naučiti iz sporta (Cumming i Ewing, 2002). Ako takav odnos izostane i dijete percipira roditeljeve postupke kao pritisak te ako izgubi osjećaj autonomije vezan uz participaciju u sportu, obiteljsko okruženje neće biti mjesto u kojemu će se dijete osjećati sretno. Roditelji tada neće biti osobe od povjerenja, ravnoteža odnosa se narušava, a time i kvaliteta djetetova socijalnog života.

\section{Povezanost kvalitete života i roditeljskog pritiska sportaša}

Inicijalno smo pretpostavili značajnu negativnu povezanost između doživljaja roditeljskog pritiska i doživljaja kvalitete života kod djece koja se bave sportom.

Tablica 6. Korelacija faktora roditeljskog pritiska $i$ faktora kvalitete života

\begin{tabular}{|c|c|c|}
\hline Faktori & $\begin{array}{l}\text { Roditeljski } \\
\text { kriticizam }\end{array}$ & $\begin{array}{l}\text { Roditeljska } \\
\text { očekivanja }\end{array}$ \\
\hline Tjelesna dobrobit & -0.01 & -0.12 \\
\hline Psihološka dobrobit & $-0.29 * *$ & -0.14 \\
\hline Raspoloženje i emocije & $0.21 *$ & $0.25 *$ \\
\hline Samopoimanje & $0.25 *$ & 0.05 \\
\hline Slobodno vrijeme & $-0.12 *$ & -0.06 \\
\hline Obiteljsko okruženje & $-0.25 *$ & -0.18 \\
\hline Novac & $-0.23 *$ & -0.2 \\
\hline Druženje & -0.03 & -0.08 \\
\hline Prijatelji & $-0.21 *$ & -0.05 \\
\hline Školsko okruženje & $-0.30 * *$ & -0.13 \\
\hline Nasilje & 0.16 & 0.08 \\
\hline Ukupna kvaliteta života & $-0.21 *$ & -1.00 \\
\hline
\end{tabular}

Korelacijska analiza faktora kvalitete života i faktora roditeljskog pritiska (Tablica 6) otkriva da roditeljski kriticizam negativno korelira s većim brojem faktora kvalitete života. Najveće korelacije u negativnom smjeru dobivene su za faktor psihološka dobrobit i školsko okruženje, što znači da kritika od strane roditelja doprinosi manje ugodnom doživljaju i zadovoljstvu životom kod djete- ta, manjoj sreći zbog postojanja, općenito narušava djetetovo dobro raspoloženje te zadovoljstvo školskim rezultatima i subjektivan doživljaj uspjeha u školi. Veliku negativnu korelaciju s kriticizmom ima i faktor zadovoljstva obiteljskim okruženjem što znači da roditeljska kritika narušava atmosferu i osjećaj sreće u obitelji, što nadalje pokazuje da participacija u sportu može djelovati na obitelj kao zajednicu. Roditeljska kritika ima pozitivne korelacije s faktorom samopoimanja i faktorom raspoloženja i emocija. Faktor samopoimanje mjeri djetetovu sliku o sebi koja se pogoršava s prisutnošću negativne roditeljske kritike. Faktor raspoloženja i emocija izražava odsustvo negativnih emocija i raspoloženja. Rezultati pokazuju da što su roditelji više kritički raspoloženi prema djetetu, to će biti i veća prisutnost negativnih emocija i raspoloženja u djece sportaša. Roditeljski je kriticizam, sukladno rezultatima, negativno povezan i s ukupnom percepcijom kvalitete života mladih sportaša (Tablica 6).

Roditelji predstavljaju važan izvor povratnih informacija o kvaliteti sportske izvedbe, a svojim očekivanjima nerijetko oblikuju standarde sportskog uspjeha (Anshel i sur., 2009, Horn i Horn, 2007, prema Greblo, 2011), pa ovakav rezultat ne iznenađuje. Prema kvalitativnom istraživanju Keegan i suradnika (2009), koji su istraživali utjecaj roditelja na motivaciju za bavljenje sportom, $\mathrm{u}$ djece tzv. pozitivnost, tj. pozitivne povratne informacije nakon sportskog natjecanja, pozitivni emocionalni odgovori roditelja, pozitivni razgovori u kojima roditelj pruža podršku pozitivno su korelirani s dječjom motivacijom za bavljenje sportom. Povratna informacija roditelja, ako je izražena $u$ obliku kritike djeluje na dječju motivaciju i sukladno rezultatima ovog istraživanja na više dimenzija kvalitete života mladih sportaša. Nadalje, roditeljska očekivanja značajno su povezana samo s rezultatom na faktoru raspoloženje i emocije što pokazuje pozitivnu povezanost između visokih roditeljskih očekivanja i neugodnih emocija i raspoloženja. Drugim riječima, ako roditelji u većoj mjeri izražavaju svoja visoka očekivanja, riskiraju da se njihova djeca osjećaju tužno, nezadovoljno, bezvoljno, zasićeno i pod stresom. Ukupan rezultat percepcije kvalitete života u značajnoj je negativnoj korelaciji s roditeljskim kriticizmom, na temelju čega se i druga hipoteza može prihvatiti kao 
točna. Može se zaključiti da roditeljski pritisak doprinosi manjem zadovoljstvu životom i manje pozitivnom doživljaju kvalitete života mladih sportaša. Djetetov doživljaj roditeljskog ponašanja, što je empirijski dokazano, povezan je s emocionalnim i socijalnim ishodima razvoja djeteta (Lengua i sur., 2007, prema Janković i Laklija, 2011). Ovim istraživanjem pokazalo se da djeca doživljavaju roditeljski pritisak najviše kroz roditeljsku kritiku i roditeljska visoka očekivanja te da potonje varijable, posebice roditeljski kriticizam, doprinose negativnijem doživljaju različitih aspekata kvalitete života djece sportaša.

Znastveni doprinos ovog istraživanja očituje se u verifikaciji Uptnika roditeljskog pritiska u sportu, instrumenta koji omogućava procjenu važne varijable koja doprinosi doživljaju stresa kod mladih sportaša, te posredno i dugoročno može narušiti motivaciju i sam sportski rezultat. Dobiveni rezultati koji ukazuju na povezanost osjećaja roditeljskog pritiska i kvalitete života mladih sportaša moguće je kreirati određene preventivne mjere $i$ psihoedukativne programe za roditelje u sportu s ciljem preveniranja ili korigiranja takvih problema u praksi, te sprečavanja osipanja djece i mladih iz sporta, što je sveprisutan fenomen u sportu u pubertetu i ranoj adolescenciji. Ograničenja ovog istraživanja tiču se uzorka sudionika koji je sačinjen samo od dječaka. U budućim bi istraživanjima ovu problematiku trebalo ispitati na većem uzorku i na suprotnom spolu, te ispitati spolne razlike.

\section{ZAKLJUČAK}

Ispitane su razlike u percepciji kvalitete života između mladih sportaša i nesportaša. Oba poduzor- ka procjenjuju svoju KŽ relativno visoko, a procjene su im vrlo slične. Rezultati ukazuju na to da se sportaši i nesportaši te dobi očekivano ne razlikuju značajno u ukupnom doživljaju kvaliteti života, ali se razlikuju u dimenzijama percepcije tjelesne dobrobit i zadovoljstva obiteljskim okruženjem. Može se zaključiti da viša razina kvalitete života mladih sportaša dominantno proizlazi iz većeg osjećaja tjelesne forme, drugim riječima osjećaju se bolje i tjelesno snažnije od njihovih vršnjaka koji nisu uključeni u organizirano bavljenje sportom i natjecanje. Nesportaši više vrednuju dobro funkcioniranje obitelji i dobar odnos s roditeljima, koji u njihovom slučaju u većoj mjeri pridonosi doživljaju kvalitete života.

Ispitana je i faktorska struktura URPS. Upitnik je po prvi puta korišten, a metrijske karakteristike ukazuju da upitnik treba daljnju doradu u smislu poboljšanja osjetljivosti. Preporučljivo bi bilo dodati još čestica kako bi se sveobuhvatnije obuhvatio koncept roditeljskog pritiska. Korelacijska analiza pokazuje da postoji uglavnom negativna povezanost između roditeljskog kriticizma i varijabli kvalitete života, a sukladno nalazu ovog istraživanja roditeljska očekivanja nisu značajno povezana s ukupnom kvalitetom života mladih sportaša osim u dimenziji dominantnog raspoloženja i emocija, a rezultati ukazuju da s porastom roditeljskih očekivanja raste i prisutnost negativnih emocija $i$ raspoloženja kod djece sportaša. 


\section{LITERATURA}

Ajduković, M. i Kolesarić, V. (2003): Etički kodeks istraživanja s djecom. Zagreb: Državni zavod za zaštitu obitelji, materinstva i mladeži i Vijeće za djecu Vlade Republike Hrvatske.

Barić, R. i Horga, S. (2006): Psihosocijalni i odgojni aspekti interakcije trenera i djeteta sportaša. U: Grgurić, J. i Batinica, M. (Ur.): Zbornik radova XVIII. Simpozija socijalne pedijatrije "Sport i zdravlje djece i mladih" (str. 78-83). Zagreb: Quo vadis tisak.

Biddle, S. \& Mutrie, N. (2008): Psychology of Physical Activity: Determinants, Well-Being and Interventions ( 2nd Ed.). New York: Routledge.

Brettschneider, W. \& Naul, R. (2004): Study on young people's lifestyles and sedentariness and the role of sport in the context of education and as a means of restorig the balance: Final report. Paderborn: EU Commission; Retrived 22 November, 2012 from: http://ec.europa.eu/sport/library/documents/c1/doc374_en.pdf

Cumming, S. P. \& Ewing, M. E. (2002): Parental Involvement in Youth Sports: The Good, the Bad and the Ugly; Retrived 28 September, 2015 from :http://www.skisport.fi/@Bin/4999/Parental+Involvement+in+Youth+Sports.pdf

Coakley, J. (2006): The good father: Parental expectations and youth sports, Leisure studies, 25(2), 153-163.

Collins, A. W. \& Laursen, B. (2005): Parent-adolescent relationships and influences. In: R. M Lerner. (Ed.). Handbook of adolescent psychology (2nd Ed.). New Jersey: John Wiley and Sons, Inc.

Doupona, M. i Petrovič, K. (1997): Sport kao kakvoća življenja (Slučaj mladih). Kineziologija, 29(1). 21-24.

Duda, J.L. (1992): Motivation in sports settings: A goal perspective approach. In: G. Roberts (Ur.), Motivation in sport and exercise (pp. 57-92). Champaign, IL: Human Kinetics.

Everitt, B. S. (2002): The Cambridge dictionary of statistics (2nd Ed.). Cambridge: Cambridge University Press.

Fraser-Thomas, J., Côté, J. \& Deakin, J. (2008): Examining Adolescent Sport Dropout and Prolonged Engagement from a Developmental Perspective, Journal of Applied Sport Psychology, 20, 318-333.

Fry, M.D. \& Newton, M. (2003): Application of achievement goal theory in an urban youth tennis setting, Journal of Applied Sport Psychology, 15, 50-66.

Gaspar, T., de Matos, M. M. N. G., Ribeiro, J. L. P., Leal, I., Erhart, M. \& Ravens-Sieberer, U. (2012): Kidscreen: Quality of life in children and adolescents, Revista de Psicologia da Criança e do Adolescente, 1(1), 49-64.

Greblo, Z. (2011): Perfekcionizam u darovitih sportaša: uloga osobinskih i okolinskih činitelja. Neobjavljena doktorska disertacija, Zagreb: Sveučilište u Zagrebu, Filozofski fakultet.

Hellstedt, J. C. (1987): The coach/parent/athlete relationship. The Sport Psychologist, 1(2), 151-160.

Hellstedt, J. C. (1990): Early adolescent perceptions of parental pressure in the sport environment, Journal of sport behavior, 13(3), 135-144.

Holt, N. \& Black, D. E. (2007): Parenting styles and specific parenting strategies in youth sport, Journal of sport and exercise psychology, 29, 170.

Holt, N. L., Tamminen, K. A., Black, D. E., Sehn, Z. L. \& Wall, M. P. (2008): Parental involvement in competitive youth settings, Psychology of Sport and Exercise, 9, 663-685.

Hong, S. D., Yang, J. W., Jang, W. S., Byun, H., Lee, M. S., Kim, H. S., ... \& Kim, J. H. (2007): The KIDSCREEN-52 quality of life measure for children and adolescents (KIDSCREEN-52-HRQOL): reliability and validity of the Korean version, Journal of Korean medical science, 22(3), 446-452.

Horga, S. (2009): Psihologija sporta. Zagreb: Školska knjiga.

Hoyle, R.H. \& Leff, S.S. (1997): The role of parental involvement in youth sport participation and performance, Adolescence, 32(125), 233-243. 
Janssen, I. \& LeBlanc, A. G. (2010): Systematic review of the health benefits of physical activity and fitness in school-aged children and youth, International Journal of Behavioral Nutrition and Physical Activity, 7(40), 1-16.

Janković, J. i Laklija, M. (2011): Povezanost ranih roditeljskih poruka i neželjenih oblika ponašanja djece osnovnoškolske dobi, Kriminologija i socijalna integracija, 19(2), 1-122.

Justinić, J. i Kuterovac-Jagodić, G. (2010): Odjeća (ne) čini adolescenta: samopoimanje i potrošačka uključenost u kupovinu odjeće s markom, Društvena istraživanja, 19,1-2(105-106), 187-208.

Kanters, M. A. \& Casper, J. (2008): Supported or Pressure? An Examination of Agreement among Parents and Children on Parent's Role in Youth Sports, Journal of sport behavior, 31(1), 64.

Keegan, R. J., Harwood, C. G., Sprayb, C. M. \& Lavallee, D. E. (2009): A qualitative investigation exploring the motivational climate in early career sports participants: Coach, parent and peer influences on sport motivation, Psychology of Sport and Exercise, 10(3), 361-372.

Klarin, M. (2006). Razvoj djece u socijalnom kontekstu: roditelji, vršnjaci, učitelji - kontekst razvoja djeteta. Jastrebarsko; Zadar: Sveučilište u Zadru, Naklada Slap.

Krizmanić, M. i Kolesarić, V. (1989): Pokušaj konceptualizacije pojma "kvaliteta života”, Primijenjena psihologija, $10,179-184$.

Lauer, L., Gould, D., Roman, N. \& Pierce, M. (2010): Parental behaviors that affect junior tennis player development, Psychology of sport and exercise, 11, 487-496.

Lorger, M. (2011): Sport i kvaliteta života mladih. Neobjavljena doktorska disertacija, Zagreb: Kineziološki fakultet Sveučilišta u Zagrebu.

Lorger, M. i Barić, R. (2012): Metrijske karakteristike hrvatske verzije Upitnika kvalitete života za djecu i adolescente The Kidscreen-52, Napredak, 153(3-4), 373-398.

Omli, J. \& Wiese-Bjornstal, D. M. (2011): Kids speak: Preferred parental behaviour at youth sport events, Research Quarterly for Exercise and Sport, 82(4), 702-711.

Ommundsen, Y., Roberts, G. C., Lemyre, P. N. \& Miller, B. W. (2006): Parental and coach support or pressure on psychosocial outcomes of pediatric athletes in soccer, Clinical journal of sport medicine, 16(6), 522-526.

O’Rourke, D. J., Smith, R. E., Smoll, F. L., \& Cumming, S. P. (2011): Trait anxiety in young athletes as a function of parental pressure and motivational climate: is parental pressure always harmful?, Journal of Applied Sport Psychology, 23(4), 398-412.

Partridge, J. A. R., Brustad \& M. Babkes Stellino (2008): Social influence in sport. In:. T. Horn (Ed.), Advances in Sport Psychology (pp. 269-291) Champaign, Il: Human Kinetics.

Petitpas, A., Cornelius, A., Van Raalte, J. \& Jones, T. (2005): A framework for planning youth sport programs that foster psychosocial development, The Sport Psychologist, 19, 63-80.

Petrušić, K. (2012): Razlike u doživljaju kvalitete života adolescenata gimnazijalaca Zagrebačke, Virovitičko-podravske i Zadarske županije. Neobjavljeni diplomski rad, Zagreb: Kineziološki fakultet Sveučilišta u Zagrebu.

Pucci G. C. M. F.,Rech C. R., Fermino, R. C. \& Reis, R. S. (2012) Association between physical activity and quality of life in adults, Rev Saude Publica, 46(1), 1-10.

Ravens-Sieberer U., Gosch A., Abel T., Auquier P. , Bellach B., Bruil J., Dur W., Power M., Rajmil L. \& European Kidscreen Group (2001): Quality of life in children and adolescents: a European public health perspective, Soz. - Praventivmed.46, 294-302.

Ravens-Sieberer, U., Herdman, M., Devine, J., Otto, C., Bullinger, M., Rose, M. \& Klasen, F. (2014): The European KIDSCREEN approach to measure quality of life and well-being in children: development, current application, and future advances, Quality of life research, 23(3), 791-803. 
Sacks, D. N., Tenenbaum, G. \& Pargman, D. (2008): Providing sport psychology services to families. In: Dosil, J. (Ed.). The sport psychologist's handbook: A guide for sport specific performance enhancement (2nd Ed.). The Atrium Southern Gate, Chichester, West Sussex: John Wiley and Sons, Ltd.

Sagar, S. \& Stoeber, J. (2009): Perfectionism, fear of failure, and affective responses to success and failure: the central role of fear of experiencing shame and embarrassment, Journal of sport \& exercise psychology, 31(5), $602-627$.

Sánchez-Miguel, P. A., Leo, F. M., Sánchez-Oliva, D., Amado, D. \& García-Calvo, T. (2013): The importance of parents' behavior in their children's enjoyment and amotivation in sports, Journal of human kinetics, 36(1), 169-177.

Shoup, J., Gattshall, M., Dandamudi, P. \& Estabrooks, P. (2008): Physical activity, quality of life, and weight status in overweight children, Qual Life Res, 17, 407-412.

Slutzky, C. B., \& Simpkins, S. D. (2009): The link between children's sport participation and self-esteem: Exploring the mediating role of sport self-concept, Psychology of Sport and Exercise, 10(3), 381-389.

Smith, R.E. \& Smoll, F.L. (2002): Youth sports as a behavior setting for psychological interventions. In: J.L. Van Raalte \& B.W. Brewer (Ed.), Exploring sport and exercise psychology (pp. 341-371). Washington, DC: American Psychological Association.

Stein, G. L., Raedeke, T. D. \& Glenn, S. D. (1999): Children's perceptions of parent sport involvement: It's not how much, but to what degree that's important. Journal of Sport Behavior, 22(4), 591-601.

Tebe, C., Berra, S., Herdman, M., Aymerich, M., Alonso, J. \& Rajmil, L. (2008): [Reliability and validity of the Spanish version of the KIDSCREEN-52 for child and adolescent population], Medicina clínica, 130(17), 650-654.

Tzavara, C., Tzonou, A., Zervas, I., Ravens-Sieberer, U., Dimitrakaki, C. \&i Tountas, Y. (2012): Reliability and validity of the KIDSCREEN-52 health-related quality of life questionnaire in a Greek adolescent population, Annals of general psychiatry, 11(3), 1-7.

Ullrich-French, S. \& Smith, A. L. (2006): Perceptions of relationships with parents and peers in youth sport: Independent and combined prediction of motivational outcomes, Psychology of sport and exercise, 7(2), 193-214.

Warburton, D., Whitney Nicol, C. \& Bredin, S. (2006): Health benefits of physical activity: the evidence, Canadian Medical Journal, 174(6), 801-809.

Wuerth, S., Lee, M. J. \& Alfermann, D. (2004): Parental involvement and athlete's career in youth sport, Psychology of sport and exercise, 5, 21-33.

\section{PARENTAL PRESSURE AND QUALITY OF LIFE AMONG YOUNG ATHLETES}

\footnotetext{
Abstract: The aims of this investigation were to examine the differences between young athletes and non-athletes in perceived quality of life, to test metric characteristics of the Parental Pressure in Sport Questionnaire (PPSQ), and to investigate the relationship between parental pressure and quality of life among young athletes. The sample comprised 100 young athletes (Mage $=12.4 \mathrm{yr}$ ) and 71 non-athletes (Mage = $12.5 \mathrm{yr}$ ). Quality of life was measured using The Kidscreen - 52 questionnaire (Lorger, Barić, 2012) comprising 11 subscales. The results showed that young athletes and non-athletes perceived themselves to have similar overall quality of life, but young athletes reported significantly higher physical well-being and significantly lower satisfaction with family environment. The PPSQ, applied here for the first time, showed satisfactory reliability but relatively low sensitivity. Factor analysis identified two components of parental pressure: parental criticism, which correlated negatively with quality of life, and parental expectations, which did not correlate significantly with quality of life.
}

Key words: Kidscreen-52, parental criticism, parental expectations, quality of life, sport, young athletes 